\title{
Students Motivation and Understanding of Football Using Android Media
}

\author{
Bambang Gatot Sugiarto ${ }^{1}$ \\ DOI: $10.35445 /$ alishlah.v13i2.575
}

\begin{tabular}{|c|c|}
\hline Article Info & Abstract \\
\hline $\begin{array}{l}\text { Keywords: } \\
\text { Learning motivation; } \\
\text { Understanding; } \\
\text { Android media }\end{array}$ & $\begin{array}{l}\text { In this pandemic period, a teacher must use effective media in the learning } \\
\text { process to increase student understanding and motivation. This study aimed to } \\
\text { see differences in student motivation and understanding in learning football } \\
\text { material before and after using android media. This research is quantitative } \\
\text { research with a pre and post-test design group. The population in this study was } \\
\text { the eighth class of VIII SMPN } 1 \text { Cimahi, Cimahi Regency, the academic year } \\
\text { 2020-2021 in August. The sample in this study was in the eighth class of SMPN } \\
1 \text { Cimahi. Statistical analysis used a parametric test if it fulfilled the classical } \\
\text { assumptions. The results showed increased student motivation and } \\
\text { understanding of football material before and after implementing learning } \\
\text { using Android media. Through these results, the teacher can use Android to } \\
\text { learn, especially during a pandemic like now. }\end{array}$ \\
\hline
\end{tabular}

Kata kunci:

Motivasi belajar;

Pemahaman;

Media android

\begin{abstract}
Abstrak
Di masa pandemik ini seorang guru harus menerpakan media yang efeketif dalam proses pembelajaran sehingga pemahaman dan motivasi siswa dapat meningkat. Tujuan dari penelitian ini adalah untuk melihat perbedaan motivasi dan pemahaman siswa dalam belajar materi sepakbola sebelum dan sesudah menggunakan media android. Penelitian ini merupakan penelitian kuantitatif dengan desain pre and postes design group. Populasi dalam penelitian ini adalah kelas VIII SMPN 1 Cimahi Kabupaten Cimahi tahun pelajaran 2020-2021 pada bulan Agustus. Sampel dalam penelitian ini di kelas VIII A SMPN 1 Cimahi. Instrumen penelitian menggunakan angket motivasi dan tes pemahaman siswa. Analisis statistik menggunakan uji paramterik jika memenuhi asusmsi klasik. Hasil penelitian menunjukan bahwa terdapat peningkatan motivasi dan pemahaman siswa dalam materi sepakbola sebelum dan sesudah melaksanakan pembelajaran dengan menggunakan media android. Melalui hasil ini guru dapat menggunakan android sebagai alternatif dalam melaksanakan pembelajaran khusunya pada masa pandemic seperti sekarang ini
\end{abstract}

${ }^{1}$ STKIP Pasundan, Cimahi, Indonesia

Email: bambanggs@stkippasundan.ac.id 


\section{INTRODUCTION}

One of the successes of a person in learning is determined by his motivation in education. Motivation is related to a person's ability to do something on impulse with a supportive environment (Keegan et al., 2010). Students who have good motivation have a good attitude, and this is shown when they are given the assignment to do something from the teacher (E. Kim, 2018) (Y. Kim et al., 2017). People who have high motivation will be enthusiastic about doing their work compared to students who do not have high enthusiasm. Therefore, motivation affects students in achieving the desired achievement (Spittle \& Byrne, 2009).

In physical education subjects, student motivation is essential in learning. Students can use motivation to develop their abilities in studying the material to quickly practice what is understood (S. Kim et al., 2020). Through motivation, students get used to the spirit of learning. Motivation can be used by someone to reduce tension when competing in a sporting event (Vlachopoulos et al., 2000)(Wallhead et al., 2014). Reducing uncertainty in the case that he can control his emotions when competing in a state of readiness and with a low level of anxiety (Sepriadi, 2019).

Motivation is divided into two types, and some motivations arise from within (intrinsic) and some from outside (extrinsic). (Vlachopoulos et al., 2000)(Spittle \& Byrne, 2009) (S. Kim et al., 2020). Internal motivation is encouragement from someone to do something of their own accord. In other words, he has his motive for doing it (Heilat \& Seifert, 2019)(Ednie \& Stibor, 2017). In terms of learning, the strongest intrinsic motivation underlies a person is because that person wants to excel in that field (Houser, 2006). While external motivation is the motivation that arises from outside, for example, he has a good environment. He is motivated by his friends to do something to get the best results. (Chen et al., 2019)(Heilat \& Seifert, 2019). Both intrinsic motivation and extrinsic motivation need to be considered by teachers to have good results in physical education subjects. Motivation is a strong impetus for someone to achieve something. Motivation is essentially a person's awareness of having the nature of his responsibility. The motivation that exists in a person will appear when he has high aspirations to achieve his goals. It is why motivation is so important in the context of achieving specific goals.

Football is a game that relies on team cohesiveness and the maturity of the coach in carrying out instructions during matches. Nevertheless, in football, the psychology of the player determines the success in every game. One of the essential elements that players must have in a football match is motivation to compete (Kiliç et al., 2015)(Chrysidis et al., 2020). Through solid motivation, a player can play well on the field. To grow motivation, teachers need to be wise in responding because, in a pandemic situation like today, an exciting learning process can determine student motivation in learning. (Katz et al., 2009)(Mavropoulou et al., 2019). Through good motivation, students will have good independence too (Wolters \& Benzon, 2013). One of the lessons that teachers can do in a pandemic situation like today is to use well-designed media in an android application.

Android can display various media in the learning process. Educators can use multimedia which is a combination of multiple media, both teachers and lecturers, to increase students' motivation in learning (Y. Kim \& Kim, 2013) (Rodiyana et al., 2020)(Swadesi \& Kanca, 2019a). Motivation for students in terms of the learning process is an intense desire to understand the material being studied. Strong motivation in students is formed when the environment in these students encourages the creation of good motivation. Android is a widely used platform in Indonesia, and it is noted that Indonesia is one of the most prominent Android users in the world. The underlying reason Android is commonly used in Indonesia is that its use is considered easy in terms of learning (Kugler et al., 2011)(Herjanata \& History, 2017).

Android can be designed by teachers in the online learning process whose process can be repeated by students to learn without being limited by time and can be carried out anywhere (Wicahyani et al., 2018)(Hoerunnisa et al., 2019). Android, being easy to use, can add animation elements in it so that the process of understanding material for students can run well because of the 
dynamic nature of learning and easy to apply. (Sri Mulyani, 2018)(Fister et al., 2014). Understanding football material, of course, requires suitable media to learn it. This is because there is a strong impetus for students to learn well. Android media, in this case, becomes a strong impetus in terms of students learning soccer material. It should be interpreted that the android media made it easier for students to learn anytime and anywhere so that its use can be done without knowing time limits. This concept will make it easier for students to learn well because they can repeat the learning material that the teacher has given.

Android can improve students' understanding ability in physical education has been studied by (Prima Ngandhika et al., 2018; Swadesi \& Kanca, 2019b). The results of both studies state that a well-designed android effectively improves students' understanding of physical education subjects. The exciting thing from this research is that in addition to looking at students' knowledge, it also looks at motivation during learning using Android. This study gets a more detailed picture of students' understanding and encouragement in learning to use Android. This research is more directed at the students' ability to understand the essential subject of football in 8th-grade junior high school. The material does various movement skills ranging from kicking, holding, dribbling, and shooting the ball. Through this research, it is expected that students' ability to understand the material can increase and students' motivation in learning also increases.

\section{METHOD}

This research is a type of quantitative research with a pre and post-test design group. The population in this study was class VIII of SMPN 1 Cimahi, Cimahi Regency, for the 2020-2021 academic year in August. The sample in this study was in class VIII A of SMPN 1 Cimahi. This study collaborated with physical education and health teachers for class VIII A at SMPN 1 Cimahi. The research instrument consisted of tests and non-tests. The test grid consists of an understanding of the understanding and history of football and the basic techniques of playing football.

In comparison, the non-test motivational grid consists of a strong desire to achieve, encouragement, expectations, and rewards in learning. The test consists of students' understanding of football and non-test material, namely students' motivation after learning with android media. The statistical test used is the parametric statistical test, namely the paired-sample t-test if it meets the formality requirements, and the Wilcoxon test if it does not meet the classical assumption test requirements. The hypotheses tested consisted of 2 trials of motivation and student understanding, the pairs of hypotheses were as follows:

Pair of hypotheses I

Ho: there is no difference in students' learning motivation before and after carrying out learning using android media

H1: there are differences in students' learning motivation before and after carrying out learning using android media

Hypothesis II

Ho: there is no difference in students' understanding of football material before and after carrying out learning using android media

H1: there is no difference in students' understanding of football material before and after carrying out learning using android media

\section{FINDINGS AND DISCUSSION}

The previously used Android was designed in advance by the researcher and consulted with the VIII grade teacher. Android developed already meets validation standards. Validators come from sports teachers and lecturers in the field of sports, especially soccer. Then the media was also previously validated by media experts, so the appearance of the media also met the criteria. It is done so that learning is more effective and can increase students' understanding and motivation. The design of the android application is as follows: 

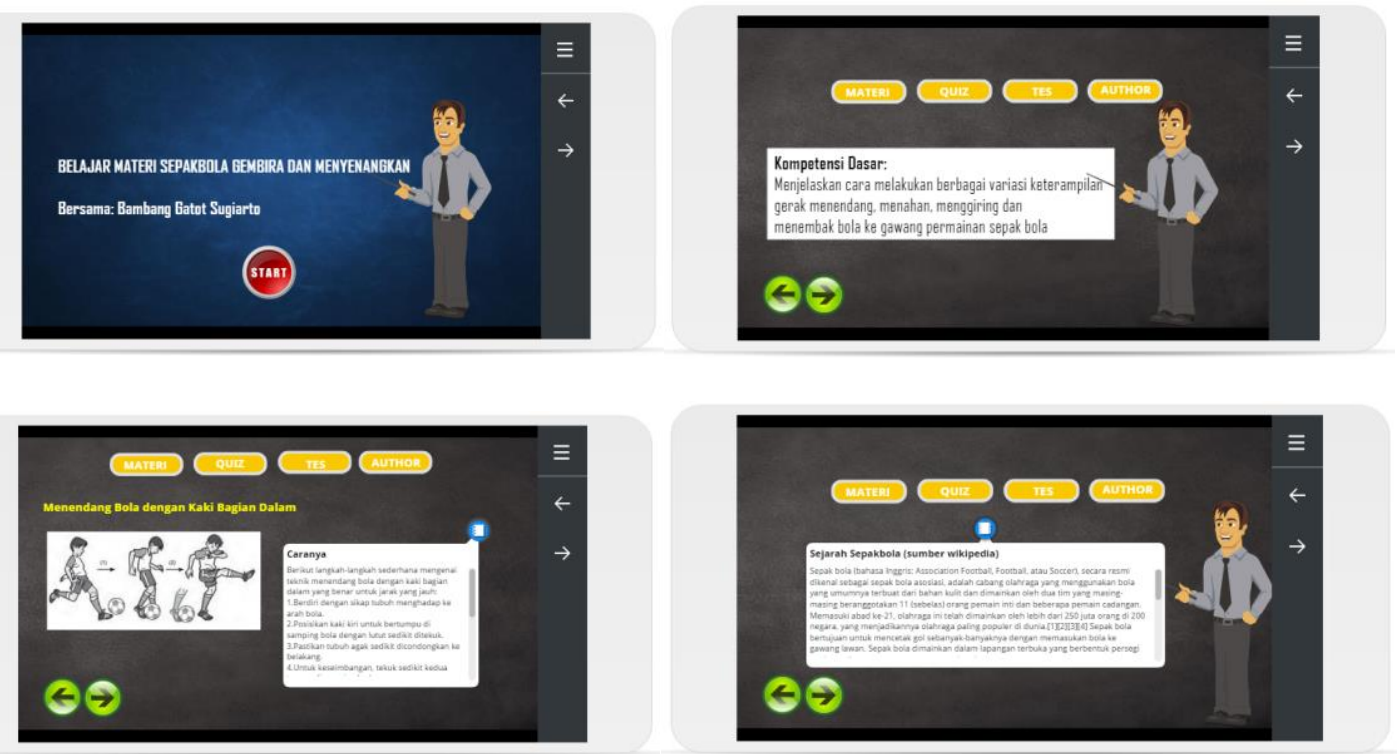

\section{Figure 1: Created Android View \\ (Source: author's document)}

After everything is considered ready and the researcher has coordinated with the SMPN 1 Cimahi teacher, the application is distributed through Google Classroom, usually used by the teacher. Before students learn with the android media, a pretest is first conducted to understand and motivate students to learn. Then after the test results are obtained, the teacher distributes the application designed to students. During $4 \mathrm{x}$ meetings, students understand football material, namely basic techniques ranging from dribbling, kicking, and holding the ball in a soccer game. All students are required to understand the material in the application. The material presented is material with soccer which is packaged starting from the history and basic techniques of playing football. The material is presented through android media that the researcher has made.

After the implementation of learning is completed for four meetings, a final test is carried out as a condition for conducting statistical tests. The test given is the same as when the pretest was presented at the beginning of the lesson. The results of the pretest and post-test can be described as follows:

Table 1. Distribution of Students' Motivation Pretest and Posttest Results

\begin{tabular}{lcccccc}
\hline & N & Minimum & Maximum & Sum & Mean & Std. Deviation \\
\hline Motivasi_Pre & 32 & 36.00 & 67.00 & 1625.00 & 50.7812 & 8.03514 \\
\hline Motivasi_Post & 32 & 66.00 & 88.00 & 2324.00 & 72.6250 & 4.96276 \\
\hline Valid N (listwise) & 32 & & & & & \\
\hline
\end{tabular}

Based on the table, it can be seen that there is a significant difference in motivation before and after learning using android media. The motivation before the average is 50.7 , while the motivation after the standard is 72.6. It shows that students' motivation has changed after the teacher learned to use android media in its delivery. In addition, the results of the pretest and post-test students' understanding are as follows:

Table 2. Distribution of Students' Understanding Pretest and Posttest Results

\begin{tabular}{ccccccc}
\hline & N & Minimum & Maximum & Sum & Mean & Std. Deviation \\
\hline Pemahaman_Pre & 32 & 50.00 & 80.00 & 2152.00 & 67.2500 & 7.66643 \\
\hline Pemahaman_Post & 32 & 77.00 & 100.00 & 2687.00 & 83.9688 & 4.92187 \\
\hline Valid N (listwise) & 32 & & & & & \\
\hline
\end{tabular}

These results illustrate that students' understanding has also increased from the previous average score of 67.25 to 83.96. It shows that students' understanding increases during learning 
using android media. To ensure that the hypothesis is accepted or rejected, it is necessary to test it with the following steps:

The classic assumption test that must be met is the normality test for both. The results of the classical normalize assumption test using Shapiro Wilk are as follows:

Table 3. Normality Test Pretest and Posttest Motivation and Understanding

\begin{tabular}{cccl}
\hline & \multicolumn{3}{c}{ Shapiro-Wilk } \\
\hline & Statistic & df & Sig. \\
\hline Motivasi_Pre & .897 & 32 & .005 \\
\hline Motivasi_Post & .914 & 32 & .014 \\
\hline Pemahaman_Pre & .966 & 32 & .405 \\
\hline Pemahaman_Post & .892 & 32 & .004 \\
\hline
\end{tabular}

The test criteria for the normality test is that the sample comes from a population that is typically distributed if the significance value is $>0.05$; in other conditions, the sample comes from a population that is not normally distributed. The results in Table 3 illustrate that only the understanding pretest has a significance value $>0.05,0.405$. In contrast, the others are less than 0.05, thus three things, namely pre and post motivation and post understanding in the normality test, do not meet the normality criteria, so the statistical test the non-parametric test used is the Wilcoxon test as a substitute for the paired-sample t-test parametric test. The pairs of hypotheses tested are as follows:

Based on the results of data processing and analysis of data analysis and accompanied by hypothesis testing, the results of the analysis test are as follows:

The test criteria reject Ho if the significance value is $<0.05$ in other conditions, Ho is accepted. The results are as follows:

Table 4. Hypothesis Testing of Motivation and Understanding

\begin{tabular}{|c|c|c|}
\hline \hline & $\begin{array}{c}\text { Motivasi_Post - } \\
\text { Motivasi_Pre }\end{array}$ & Post and Pre Understanding \\
\hline $\begin{array}{c}\text { Asymp. Sig. } \\
\text { (2-tailed) }\end{array}$ & .00o & .000 \\
\hline
\end{tabular}

Based on these data, it can be concluded that Ho is rejected for motivation and understanding. So that it can be supposed that there are differences in students' learning motivation before and after implementing learning using android media; there are differences in students' understanding of football material before and after carrying out learning using android media.

These results illustrate that motivation and understanding have increased because the teacher learns using android media. Android media aims to make it easier for students to understand the material because it is flexible, easy to use, and repeated (Kuntadi et al., 2019)(Swadesi \& Kanca, 2019a). Students' understanding seems to have increased due to android use, attracting students' interest in the learning process. This pandemic situation shows that learning using android media can be a stimulus for students to be interested in learning so that students' understanding can increase. In this study, we see that the very high number of android users in Indonesia is an opportunity for educators to develop accessible and flexible media to make it easier for students to understand the material.

The results of this study are strengthened by research (Kartini, 2020; Lubis \& Ikhsan, 2015) that using android media can improve students' cognitive abilities and learning motivation. Android is designed to be used easily so that its use can be felt by students effectively. It is following the opinion that Android is a platform that is widely used in Indonesia. It is noted that Indonesia is one of the most prominent Android users in the world. The underlying reason Android is widely used in Indonesia is that its use is considered easy in terms of learning (Kugler et al., 2011)(Herjanata \& History, 2017). The use of Android that is arranged simply on certain materials can make it easier 
for students to be interested in carrying out learning with these media. It should be underlined that intrinsic motivation is essential for educators to improve so that students want to know well (Kuntadi et al., 2019)

Intrinsic motivation arises because there is encouragement from within students to be enthusiastic about learning. Some interviewed students found that using Android made students passionate about education because it was easy to use. Some students responded that "android is easy to learn, android is simple to learn, it can be anywhere." Android media can be a suitable means of understanding the material in students. Thus good students will be able to practice what they know. This shows a motivation that educators can raise if they use media that can be used effectively and efficiently.

\section{CONCLUSION}

Based on the data processing and analysis results, it can be concluded that there is an increase in students' motivation and understanding of football material before and after learning using android media. Through these results, teachers can use Android as a supporting alternative in carrying out learning, especially during a pandemic like today. This is because android media is a suitable media and can be applied in all subjects. The limitations in this study were due to the pandemic period of difficulty in controlling students in learning to use Android. Then there were several obstacles in terms of smartphones that did not support the application used.

\section{ACKNOWLEDGMENT}

Thank you to the head of STKIP Pasundan, who has provided motivation and encouragement, and the lecturers who have helped carry out the research; not to forget the teachers at SMPN 1 Cimahi, I thank you for assisting in the smooth running of this research.

\section{REFERENCES}

Chen, C., Elliot, A. J., \& Sheldon, K. M. (2019). Psychological need support as a predictor of intrinsic and external motivation: the mediational role of achievement goals. Educational Psychology, 39(8), 1090-1113. https://doi.org/10.1080/01443410.2019.1618442

Chrysidis, S., Turner, M. J., \& Wood, A. G. (2020). The effects of REBT on irrational beliefs, selfdetermined motivation, and self-efficacy in American Football. Journal of Sports Sciences, 38(19), 2215-2224. https://doi.org/10.1080/02640414.2020.1776924

Ednie, A. J., \& Stibor, M. D. (2017). Motivation and self-efficacy among winter outdoor exercise enthusiasts. Leisure/Loisir, 41(4), 491-508. https://doi.org/10.1080/14927713.2017.1399816

Fister, I., Fister, D., Ljubič, K., Zhuang, Y., \& Fong, S. (2014). Towards automatic food prediction during endurance sport competitions. Proceedings - 2014 International Conference on Soft Computing and Machine Intelligence, ISCMI 2014, 6-10. https://doi.org/10.1109/ISCMI.2014.30

Heilat, M. Q., \& Seifert, T. (2019). Mental motivation, intrinsic motivation and their relationship with emotional support sources among gifted and non-gifted Jordanian adolescents. Cogent Psychology, 6(1), 1-13. https://doi.org/10.1080/23311908.2019.1587131

Herjanata, P. W., \& History, A. (2017). The Android-Learned Media Learning Media With Health Material For Students of Class X. ACTIVE: Journal of Physical Education, Sport, Health and Recreation, 6(3), 183-188. https://doi.org/10.15294/active.v6i3.17371

Hoerunnisa, A., Suryani, N., \& Efendi, A. (2019). E-Learning in Multimedia Classes To Improve Vocational Students ' Learning. Journal of Technology in Teaching and Learning, o7(02), 123-137.

Houser, M. L. (2006). Expectancy violations of instructor communication as predictors of motivation and learning: A comparison of traditional and nontraditional students. Communication Quarterly, 54(3), 331-349. https://doi.org/10.1080/01463370600878248 
Kartini, E. R. (2020). Bts-Bi Application (Indonesian Student Text Book) Based on Android. $A L-$ ISHLAH: Jurnal Pendidikan, 12(1), 158-175. https://doi.org/10.35445/alishlah.v12i1.174

Katz, I., Kaplan, A., \& Gueta, G. (2009). Students' needs, teachers' support, and motivation for doing homework: A cross-sectional study. Journal of Experimental Education, 78(2), 246267. https://doi.org/10.1080/00220970903292868

Keegan, R., Spray, C., Harwood, C., \& Lavallee, D. (2010). The motivational atmosphere in youth sport: Coach, parent, and peer influences on motivation in specializing sport participants. Journal of Applied Sport Psychology, 22(1), 87-105. https://doi.org/10.1080/10413200903421267

Kiliç, B., Yücel, A. S., \& Korkmaz, M. (2015). Analyzing the relation between pain status of football players and motivation. Anthropologist, 21(3), 489-499. https://doi.org/10.1080/09720073.2015.11891838

Kim, E. (2018). A systematic review of motivation of sport event volunteers. World Leisure Journal, 6o(4), 306-329. https://doi.org/10.1080/16078055.2017.1373696

Kim, S., Morgan, A., \& Assaker, G. (2020). Examining the relationship between sport spectator motivation, involvement, and loyalty: a structural model in the context of Australian Rules football. Sport in Society, o(o), 1-26. https://doi.org/10.1080/17430437.2020.1720658

Kim, Y., \& Kim, S. (2013). Segmenting sport video gamers by motivation: a cluster analysis. Journal of Global Scholars of Marketing Science, 23(1), 92-108. https://doi.org/10.108o/21639159.2012.744513

Kim, Y., Kim, S., \& Kim, Y. M. (2017). Big-Five Personality and Motivations Associated with Sport Team Social Networking Site Usage: A Cluster Analysis Approach. Journal of Global Sport Management, 2(4), 250-274. https://doi.org/10.1080/24704067.2017.1389249

Kugler, P. F., Schuldhaus, D., Jensen, U., \& Eskofier, B. M. (2011). Mobile Recording System for Sport Applications. Pattern Recognition, April 2015, 2-5.

Kuntadi, I., Widiaty, I., Yulia, C., \& Mubaroq, S. R. (2019). An android-based e-observation application on lesson study learning in vocational high schools. Journal of Engineering Science and Technology, 14(5), 2499-2508.

Lubis, I. R., \& Ikhsan, J. (2015). Pengembangan Media Pembelajaran Kimia Berbasis Android Untuk Meningkatkan Motivasi Belajar Dan Prestasi Kognitif Peserta Didik Sma. Jurnal Inovasi Pendidikan IPA, 1(2), 191. https://doi.org/10.21831/jipi.v1i2.7504

Mavropoulou, A., Barkoukis, V., Douka, S., Alexandris, K., \& Hatzimanouil, D. (2019). The role of autonomy supportive activities on students' motivation and beliefs toward out-of-school activities. Journal of Educational Research, 112(2), 223-233. https://doi.org/10.1080/00220671.2018.1503580

Prima Ngandhika, E., Raffy Rustiana, E., \& Pramono, H. (2018). Development of Android-Based Rhythmic Activity Learning Media on Physical Education in High School. Journal of Physical Education and Sports JPES, 7(2), 106-112. https://journal.unnes.ac.id/sju/index.php/jpes/article/view/23612

Rodiyana, R., Santoso, E., Puspitasari, W. D., \& Miko, H. (2020). The Effect of Multimedia in Increasing the Integers Operation Ability. Journal of Physics: Conference Series, 1477(4). https://doi.org/10.1088/1742-6596/1477/4/042057

Sepriadi. (2019). PENGARUH MOTIVASI BEROLAHRAGA DAN STATUS GIZI TERHADAP TINGKAT KEBUGARAN JASMANI Sepriadi. Journal of Chemical Information and Modeling, 53(9), 1689-1699.

Spittle, M., \& Byrne, K. (2009). The influence of Sport Education on student motivation in physical education. Physical Education \& Sport Pedagogy, 14(3), 253-266. https://doi.org/10.1080/17408980801995239

Sri Mulyani, E. W. (2018). Dampak Pemanfaatan Aplikasi Android Dalam Pembelajaran Bangun Ruang. Kwangsan: Jurnal Teknologi Pendidikan, 6(2), 122-136. 
https://doi.org/10.31800/jtp.kw.v6n2.p122--136

Swadesi, I. K. I., \& Kanca, I. N. (2019a). Learning Media Development Physical Education Sport and Health Based Applications. 335(ICESSHum), 830-840. https://doi.org/10.2991/icesshum-19.2019.130

Swadesi, I. K. I., \& Kanca, I. N. (2019b). Learning Media Development Physical Education Sport and Health Based Applications. QUALITY IN SPORT, 1(7), 37-44. https://doi.org/10.2991/icesshum-19.2019.130

Vlachopoulos, S. P., Karageorghis, C. I., \& Terry, P. C. (2000). Motivation profiles in sport: A selfdetermination theory perspective. Research Quarterly for Exercise and Sport, 71(4), 387397. https://doi.org/10.1080/02701367.2000.10608921

Wallhead, T. L., Garn, A. C., \& Vidoni, C. (2014). Effect of a sport education program on motivation for physical education and leisure-time physical activity. Research Quarterly for Exercise and Sport, 85(4), 478-487. https://doi.org/10.1080/02701367.2014.961051

Wicahyani, S., Handayani, O. W. K., \& Hartono, M. (2018). Design android applications my mind mapping (M3) physical education, sport, \& health subject curriculum 2013 for teachers guidance X th grade vocational high school. Journal of Physical Education and Sports, 7(1), $73-82$.

Wolters, C. A., \& Benzon, M. B. (2013). Assessing and predicting college students use of strategies for the self-regulation of motivation. Journal of Experimental Education, 81(2), 199-221. https://doi.org/10.1080/00220973.2012.699901 